\title{
Pengembangan Media Pembelajaran Toys for Physics Untuk Meningkatkan Pemahaman Konsep Pembelajaran Fisika di SMA
}

\author{
Vita Nuriana Reza ${ }^{1)}$, Ashari $^{2}$, Nurhidayati ${ }^{3}$ ) \\ 1), 2), 3)Universitas Muhammadiyah Purworejo, Indonesia \\ nurianavnr@gmail.com
}

\begin{tabular}{l}
\hline open \\
access \\
*Penulis Korespondensi \\
\hline Histori Artikel: \\
Submit: 2022-01-14 \\
Diterima: 2022-01-15 \\
Dipublikasikan: 2022-01-15 \\
\hline Kata Kunci: \\
Pengembangan, media \\
pembelajaran, Toys for \\
Physics, pemahaman \\
konsep, Pendidikan. \\
\hline
\end{tabular}

\begin{abstract}
ABSTRAK
Telah dilakukan penelitian tentang pengembangan media pembelajaran Toys for Physic bertujuan untuk menghasilkan suatu media pembelajaran fisika berbasis educational games berupa Toys for Physics dan mengetahui peningkatan pemahaman konsep fisika peserta didik kelas X SMA. Penelitian ini merupakan penelitian pengembangan dengan model 4-D (Define, Design, Develop, Disseminate). Berdasarkan hasil penelitian diperoleh hasil vallidasi media oleh ketiga validator diperoleh media pesebesar 3,25 dengan kategori baik dan rerata reabilitas semua validator sebesar $92 \%$ dengan kategori sangat reliabel, sedangkan hasil respon peserta didik terhadap media pengembangan Toys for Physics yang dikembangkan dengan skor sebesar 3,42 sehingga diperoleh persentase rerata 91\% dengan kategori sangat baik. Hasil pemahaman konsep peserta didik dilihat dari nilai pretest dan posttest pada tahap penerapan diperoleh $N$-gain 0,65 dan termasuk dalam kategori peningkatan sedang. Dengan demikian, dapat disimpulkan bahwa media pembelajaran Toys for Physics yang dikembangkan dalam penelitian ini dikategorikan baik dan layak digunakan sebagai alternatif dalam pembelajaran Fisika serta dapat meningkatkan pemahaman konsep peserta didik.
\end{abstract}

\section{LATAR BELAKANG}

Pembelajaran menurut UU No. 20 tahun 2003 tentang sisdiknas adalah proses interaksi peserta didik dengan pendidik dan sumber belajar pada suatu lingkungan belajar. Salah satu komponen penting dalam pembelajaran adalah media pembelajaran sebagai alat bantu mengajar.

Media merupakan suartu perantara atau pengantar yang jika dipahami secara garis besar adalah manusia, materi dan kejadian yang membangun kondisi yang membuat pesera didik mampu memperoleh pengetahuan, ketrampilan atau sikap. Dalam pengertian ini, guru, buku teks, dan lingkungan sekolah merupakan suatu media [1]. Media pembelajaran merupakan alat bantu mengajar yang ada dalam komponen metodologi, sebagai salah satu lingkungan belajar yang diatur oleh pendidik [2]. Media dapat meningkatkan proses belajar peserta didik dalam pembelajaran. Dalam pembelajaran fisika biasanya pendidik menggunakan media pembelajaran serbaneka (papan) dan media audio visual (Microsoft PowerPoint) [2]. Pada umumnya, pembelajaran di sekolah menggunakan metode ceramah yang kurang efektif untuk peserta didik, karena lebih cenderung bersikap pasif dan komunikasinya hanya berjalan satu arah dari pendidik ke peserta didik. Dengan metode ceramah hanya menuntut peserta didik untuk menghafal bukan memahami konsepnya. 
Konsep merupakan gambaran dari suatu hal yang didasarkan pada sifat yang dimilikinya [3]. Kemampuan pemahaman konsep pesera didik adalah kemampuan pesera didik dalam menuliskan konsep, memberi contoh dan bukan contoh dari konsep, mengaplikasikan konsep ke pemecahan masalah. Pemahaman terhadap bahan pelajaran itu dapat diperkuat bila disajikan latihan-latihan soal yang berhubungan dengan bahan yang disajikan itu[4]. Adapun indikator pemahaman konsep ada tujuh yaitu, Kemampuan Interpretasi (Interpreting), Kemampuan Memberi Contoh (Exemplifying), Kemampuan Mengklasifikasi (Classifying), Kemampuan Meringkas (Summarizing), Kemampuan Menyimpulkan (Inferring), Kemampuan Membandingkan (Comparing), dan Kemampuan Menjelaskan (Explaining) [5].

Pembelajaran fisika di SMA saat ini cenderung belum mendorong peserta didik untuk memahami fisika secara sistematis dan konseptual, serta meningkatkan kemampuan pemecahan masalah secara mandiri. Untuk itu, alat bantu atau media yang membuat peserta didik merasa senang dan termotivasi untuk belajar mandiri sangat dibutuhkan dalam proses pembelajaran untuk menciptakan kualitas peserta didik yang tidak hanya bergantung melalui transfer ilmu secara verbal yang dilakukan oleh sekolah ataupun lembaga pendidikan nonformal pada saat ini. Pembelajaran fisika di SMA saat ini cenderung belum mendorong peserta didik untuk memahami fisika secara sistematis dan konseptual, serta meningkatkan kemampuan pemecahan masalah secara mandiri. Untuk itu, alat bantu atau media yang membuat peserta didik merasa senang dan termotivasi untuk belajar mandiri sangat dibutuhkan dalam proses pembelajaran untuk menciptakan kualitas peserta didik yang tidak hanya bergantung melalui transfer ilmu secara verbal yang dilakukan oleh sekolah ataupun lembaga pendidikan nonformal pada saat ini. Salah satu upaya menciptakan situasi belajar yang menyenangkan, hidup, dan santai dalam proses belajar peserta didik adalah dengan mengajak peserta didik bermain sambil belajar. Dalam bermain juga terjadi proses belajar [6].

Berdasarkan latar belakang di atas, peneliti tertarik untuk melakukan penelitian tentang pengembangan media pembelajaran Toys for Physics untuk meningkatkan pemahaman konsep pembelajaran fisika di SMA. Penelitian ini bertujuan untuk mengetahui: (1) kelayakan media pembelajaran Toys for Physics pada pembelajaran Fisika SMA, (2) respon peserta didik terhadap media pembelajaran Toys for Physics, dan (3) peningkatan pemahaman konsep peserta didik setelah menggunakan media pembelajaran Toys for Physics yang telah dikembangkan.

\section{STUDI LITERATUR}

Penelitian yang dilakukan oleh [7] tentang pengembangan media pembelajaran fisika berbasis model educational games guna meningkatkan minat dan hasil belajar melalui Rolling Box (RO-BOX) bagi peserta didik kelas X. pada penelitian ini diperoleh hasil bahwa produk yang dikembangkan berupa media pembelajaran fisika berbasis model educational games guna meningkatkan minat dan hasil belajar melalui Rolling Box (RO-BOX) memiliki kualitas yang baik berdasar penilaian pakar dan mendapat respon yang positif dari guru beserta peserta didik peningkatan minat belajar peserta didik dengan persentase ketercapaian sebesar 3,7 \% termasuk dalam kategori baik. Dan peningkatan hasil belajar peserta didik dengan nilai standar gain sebesar 0,84 yang termasuk dalam kategori tinggi.

Penelitian serupa dilakukan oleh [8] tentang pengembangan media pembelajaran gamesroulette fisika untuk meningkatkan motivasi dan hasil belajar peserta didik. Berdasarkan analisis angket motivasi belajar fisika sebelum dan sesudah menggunakan media ge-roul dapat diketahui bahwa pada uji coba terbatas memiliki nilai normalized gain sebesar 0,55 sedangkan pada uji coba lapangan memiliki nilai 
normalized gain sebesar 0,40. Dengan demikian, dapat disimpulkan bahwa motivasi belajar fisika setelah diberikan media ge-roul pada peserta didik kelas XMIPA meningkat dengan kategori sedang karena kedua normalized gain berada pada rentang 0,3 hingga 0,7 .

Penelitian serupa dilakukan oleh [9] tentang pengembangan permainan tradisional jamuran sebagai media pembelajaran tata nama senyawa di kelas X SMA. Berdasarkan analisis angket hasil belajar peserta didik sebelum dan sesudah menggunakan media permainan tradisional jamuran diperoleh persentase ketuntasan klasikal hasil pretest adalah sebesar 40\%, sedangkan dari hasil posttest persentase ketuntasan klasikal sebesar 85\% dengan kategori sangat baik. Permainan Jamuran berpengaruh meningkatkan hasil belajar siswa kelas $\mathrm{X}$ yang ditunjukkan dari peningkatan persentase ketuntasan klasikal sebesar $45 \%$.

\section{METODE}

Penelitian pengembangan ini bertujuan untuk mengembangkan media pembelajaran Toys for Physics sehingga dapat meningkatkan pemahaman konsep peserta didik. Media pembelajaran yang dikembangkan juga disertai lembar kerja untuk memudahkan peserta didik dalam melakukan kegiatan pembelajaran. Desain penelitian pengembangan ini diadaptasi dari metode penelitian dan pengembangan, metode penelitian dan pengembangan atau Research and Development (R\&D) adalah metode penelitian yang digunakan untuk menghasilkan media pembelajaran Toys for Physics, dan menguji keefektifan produk tersebut [10]. Penelitian R\&D ini menggunakan model pengembangan 4D (Define, Design, Develop, Disseminate). Tetapi pada penelitian ini hanya menggunakan 3D atau sampai tahap ketiga pengembangan. Subjek penelitian ini terdiri atas 5 peserta didik kelas X MIPA 2 dan 17 peserta didik kelas X MIPA 1 di SMA Negeri 9 Purworejo.

Analisis data digunakan untuk memperoleh gambaran kuantitatif dari data yang dihasilkan. Teknik analisis data yang digunakan dalam penelitian ini sebagai berikut:

1. Validitas Media

Teknik analisis data untuk kelayakan lembar validasi media pembelajaran fisika dilakukan dengan cara mengumpulkan data dari validator, kemudian mengkonversikan ke dalam skala kriteria kualitatif dengan acuan seperti pada Tabel 1.

Tabel 1. Acuan Pengubahan Nilai Skala Empat

\begin{tabular}{cc}
\hline Interval skor & Interpretasi \\
\hline $0.00-1.69$ & Tidak baik \\
$1.70-2.59$ & Kurang baik \\
$2.60-3.50$ & Cukup baik \\
$3.51-4.00$ & Baik \\
\hline
\end{tabular}

Agar mempermudah dalam membandingkan skor maka perlu diubah ke dalam persentase menggunakan persamaan 1 [11] yaitu:

$N P=R S M \times 100 \%$

Keterangan:

NP : Nilai persen

$R \quad:$ Skor mentah 
SM : Skor maksimum ideal dari instrumen

2. Reabilitas

Analisis data yang ditinjau dari angket respon peserta didik dan observasi keterlaksanaan pembelajaran. Langkah analisis data respon peserta didik dilakukan dengan cara merekapitulasi data angket respon peserta didik, kemudian diubah kedalam bentuk persentase pada persamaan (1), selanjutnya dikonversikan ke dalam skala kriteria kualitatif dengan acuan nilai seperti pada Tabel 2.

Tabel 2. Kriteria Pedoman Penilaian

\begin{tabular}{cc}
\hline Tingkat Persentase $(\%)$ & Predikat \\
\hline $86 \%-100 \%$ & Sangat baik \\
$76 \%-85 \%$ & Baik \\
$60 \%-75 \%$ & Cukup baik \\
$\leq 59 \%$ & Sangat Kurang \\
\hline
\end{tabular}

Observasi keterlaksanaan pembelajaran dilakukan oleh dua pengamat. Langkah analisis data observasi keterlaksanaan pembelajaran dilakukan dengan cara merekapitulasi data respon dari kedua pengamat, kemudian menghitung Percentage Agreement (PA). PA digunakan untuk menghitung reliabilitas hasil penilaian keterlaksanaan pembelajaran yang dilakukan ketika pelaksanaan proses pembelajaran. Menurut Borich Percentage Agreement dapat ditentukan dengan persamaan 2 [12].

$P A=\left(1 \frac{A-B}{A+B}\right) \times 100 \%$

Keterangan:

PA : Percentage Agreement

A : skor tinggi dari pengamat

B : skor rendah dari pengamat

A dan B merupakan besar nilai yang diberikan pengamat pertama dan kedua dengan $\mathrm{A}>\mathrm{B}$. Instrumen dikatakan reliabel jika nilai PA $>1$ atau PA $=75 \%$ [10]. Kemudian dikonversikan menggunakan acuan kriteria PA seperti pada Tabel 3.

Tabel 3. Acuan Kriteria PA

\begin{tabular}{cc}
\hline Rentang Nilai (\%) & Kategori \\
\hline $76-100$ & Reliabel \\
$51-75$ & Cukup Reliabel \\
$26-50$ & Kurang Reliabel \\
$0-25$ & Tidak Reliabel \\
\hline
\end{tabular}

3. Analisis Keefektifan

Analisis data pretest dan posttest kemampuan analisis digunakan untuk mengetahui peningkatan kemampuan analisis peserta didik. Indikator kemampuan analisis disajikan pada Tabel 4 [13]. 
Tabel 4. Indikator Kemampuan Analisis

\begin{tabular}{cl}
\hline No & \multicolumn{1}{c}{ Indikator } \\
\hline 1. & Menyatakan Ulang \\
2. & Mengklasifikasi Objek \\
3. & Memberi Contoh \\
4. & Mengembangkan \\
5. & Menggunakan prosedur \\
6. & Menyajikan konsep \\
7. & Mengaplikasikan konsep \\
\hline
\end{tabular}

keefektifan dilakukan \begin{tabular}{llccc}
$\begin{array}{ccc}\text { Analisis } \\
\text { dengan }\end{array}$ cara & 7. & Mengaplikasikan konsep & $\begin{array}{c}\text { keefektifan } \\
\text { merekapitulasi }\end{array}$ & $\begin{array}{r}\text { dilakukan } \\
\text { data }\end{array}$ \\
\cline { 2 - 3 } perolehan skor yang diperoleh dari pretest dan posttest & kemampuan analisis, & selanjutnya
\end{tabular} menghitung N-gain dengan menggunakan persamaan 3 [14].

$g=\frac{S_{f}-S_{i}}{100-S_{i}}$

Keterangan:

$g$ : Gain ternormalisasi

$S_{f}:$ Skor posttest

$S_{i}$ : Skor pretest

Hasil perhitungan $N$-gain dikonversi ke dalam klasifikasi $N$-gain dengan kriteria seperti pada Tabel 5 [15].

Tabel 5. Kriteria $N$-gain

\begin{tabular}{cc}
\hline Kriteria & Klasifikasi \\
\hline $\mathrm{g} \geq 0,7$ & Tinggi \\
$0.3 \geq \mathrm{g}>0.7$ & Sedang \\
$\mathrm{g}<0.3$ & Rendah \\
\hline
\end{tabular}

\section{HASIL}

Berdasarkan analisis data, diperoleh hasil validasi, dan hasil uji keterlaksanaan yang disajikan sebagai berikut.

\section{Validasi Media Pembelajaran Toys for Physics}

a. Validasi Ahli Media

Data hasil validasi oleh ahli media untuk media pembelajaran toys for physics disajikan pada Tabel 6.

Tabel 6.Hasil validasi materi Toys For Physics

\begin{tabular}{lllll}
\hline \multirow{2}{*}{ No. Aspek } & \multicolumn{2}{c}{ Skor } & Rerata & \multirow{2}{*}{ Reliabilitas } \\
& Ahli & Guru & Skor & \\
\hline
\end{tabular}

Jurnal Pendidikan Sains dan Komputer is licensed under a Creative Commons Attribution-NonCommercial 4.0 International (CC BY-NC 4.0). 


\begin{tabular}{cccccc}
1 & Syarat Dikdatis & 3.50 & 3 & 3.25 & $92 \%$ \\
2 & Syarat Konstruksi & 3.67 & 3 & 3.33 & $90 \%$ \\
3 & Syarat Teknisi & 3.33 & 3 & 3.17 & $95 \%$ \\
\multirow{2}{*}{ Rerata } & 10.50 & 9 & 9.75 & $92 \%$ \\
& \multirow{2}{*}{ Kategori } & 3.50 & 3 & 3.25 & $92 \%$ \\
\hline \multirow{2}{*}{} & Sangat & \multirow{2}{*}{ Baik } & Sangat & Sangat \\
& Baik & & Baik & Reliabel \\
\hline
\end{tabular}

Diagram hasil validasi media pembelajaran Toys for Physics oleh ahli media disajikan dalam Gambar 1.

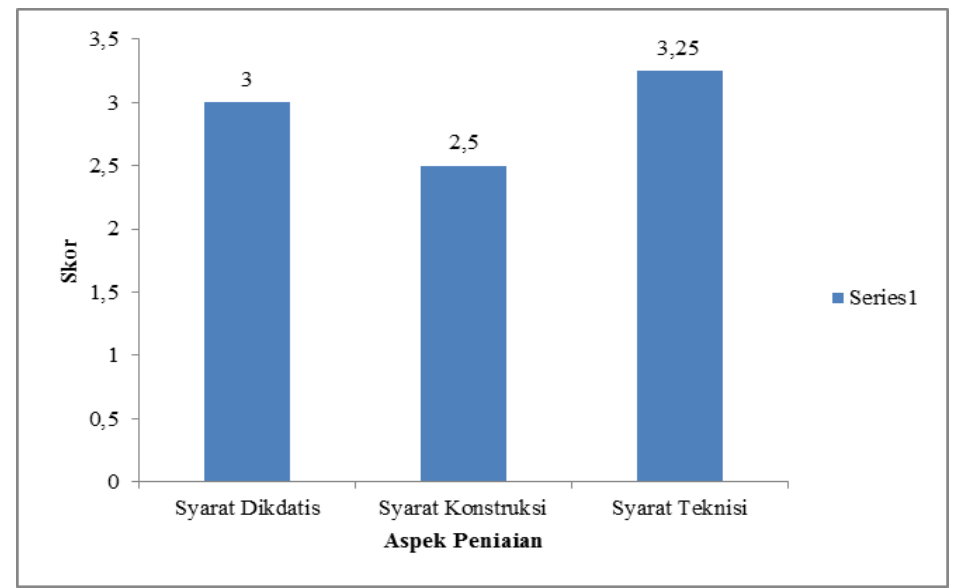

Gambar 1. Kelayakan media pembelajaran Toys for Physics oleh Ahli Media

\section{b. Validasi Ahli Materi}

Data hasil validasi oleh ahli materi untuk media pembelajaran toys for physics disajikan pada Tabel 7.

Tabel 7.Hasil validasi materi Toys for Physics

\begin{tabular}{|c|c|c|c|c|c|}
\hline \multirow{2}{*}{ No. } & \multirow{2}{*}{ Aspek } & \multicolumn{2}{|c|}{ Skor } & \multirow{2}{*}{ Rerata Skor } & \multirow{2}{*}{ Reliabilitas } \\
\hline & & Ahli & Guru & & \\
\hline 1 & Syarat Dikdatis & 3.50 & 3 & 3.25 & $92 \%$ \\
\hline 2 & $\begin{array}{c}\text { Syarat } \\
\text { Konstruksi }\end{array}$ & 3.67 & 3 & 3.33 & $90 \%$ \\
\hline 3 & Syarat Teknisi & 3.33 & 3 & 3.17 & $95 \%$ \\
\hline \multirow{2}{*}{\multicolumn{2}{|c|}{ Rerata }} & 10.50 & 9 & 9.75 & $92 \%$ \\
\hline & & 3.50 & 3 & 3.25 & $92 \%$ \\
\hline & Kategori & $\begin{array}{l}\text { Sangat } \\
\text { Baik }\end{array}$ & Baik & Sangat Baik & Sangat Reliabel \\
\hline
\end{tabular}

Diagram hasil validasi materi pembelajaran Toys for Physics oleh ahli media disajikan dalam Gambar 2. 


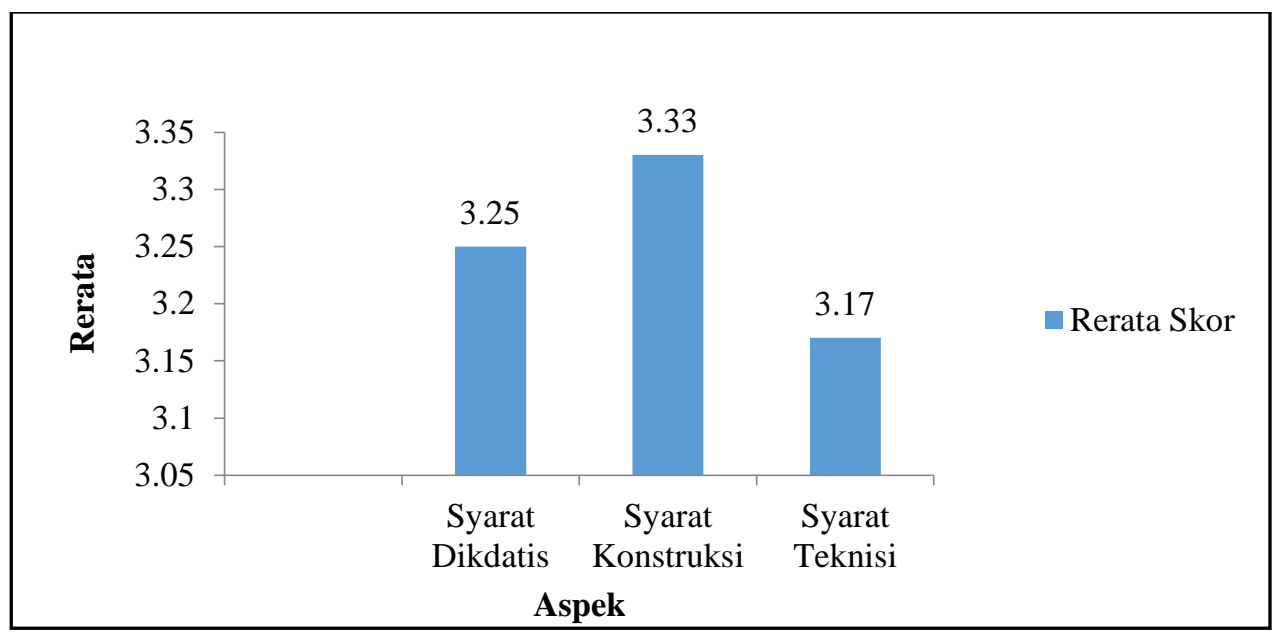

Gambar 2. Kelayakan media pembelajaran Toys for Physics oleh Ahli Materi

\section{Respon Peserta Didik Terhadap Media Pembelajaran Toys for Physics}

Data hasil respon peserta didik kelas X MIPA 1 terhadap pembelajaran dengan media pembelajaran Toys for Physics disajikan pada Tabel 8.

Tabel 8. Hasil Analisis Angket Respon Peserta Didik terhadap Media Pembelajaran Toys for Physics

\begin{tabular}{clccc}
\hline No. & \multicolumn{1}{c}{ Aspek } & Skor & Rerata Skor & Reliabilitas \\
\hline 1 & Ketertarikan & 62 & 3.39 & $86 \%$ \\
2 & Kebermanfaatan & 204 & 3.57 & $94 \%$ \\
3 & Kemudahan & 65 & 3.33 & $90 \%$ \\
4 & Kualitas & 133 & 3.39 & $92 \%$ \\
& Jumlah Tiap Aspek & & 13.69 & $363 \%$ \\
& Rerata Seluruh Aspek & & 3.42 & $91 \%$ \\
\hline \multirow{2}{*}{ Kategori } & & Baik & Sangat \\
& & & & Reliabel
\end{tabular}

Diagram Analisis Angket Respon Peserta Didik terhadap Media Pembelajaran Toys for Physics disajikan dalam Gambar 3.

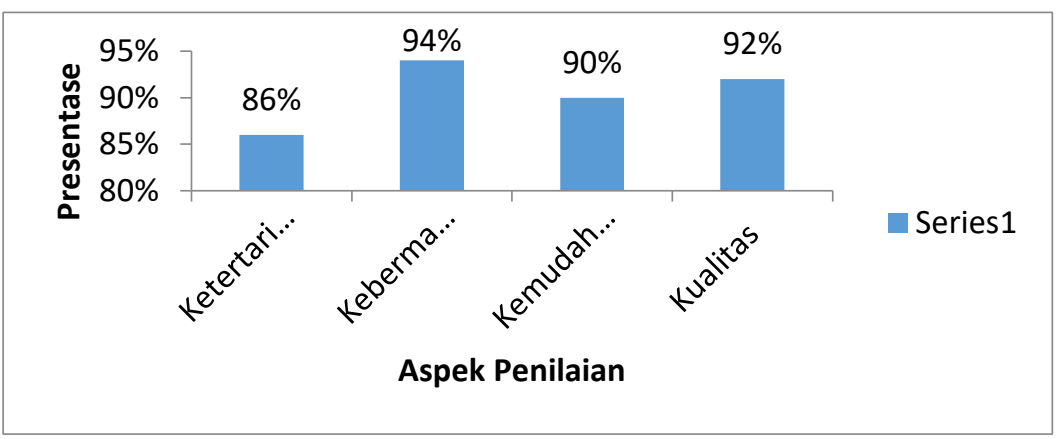

Gambar 3. Analisis Angket Respon Peserta Didik terhadap Media Pembelajaran Toys for Physics 


\section{Tes Pemahaman Konsep}

a. Hasil Analisis Pretest dan Posttest

Data hasil Pretest dan Posttest Peserta Didik terhadap Media Pembelajaran Toys for Physics untuk pemahaman konsep pada kelas X MIPA 1 disajikan pada Tabel 9.

Tabel 9.Analisis Pretest dan Posttest pada Peserta Didik

\begin{tabular}{|l|r|lr|}
\hline Tahapan & Jumlah & Rerata \\
\hline Pretest & 790 & 4,62 \\
\hline Posttest & 1380 & & 8,11 \\
\hline
\end{tabular}

Diagram hasil Analisis Pretest dan Posttest Peserta Didik terhadap Media Pembelajaran Toys for Physics untuk pemahaman konsep pada kelas X MIPA 1 disajikan dalam Gambar 3.

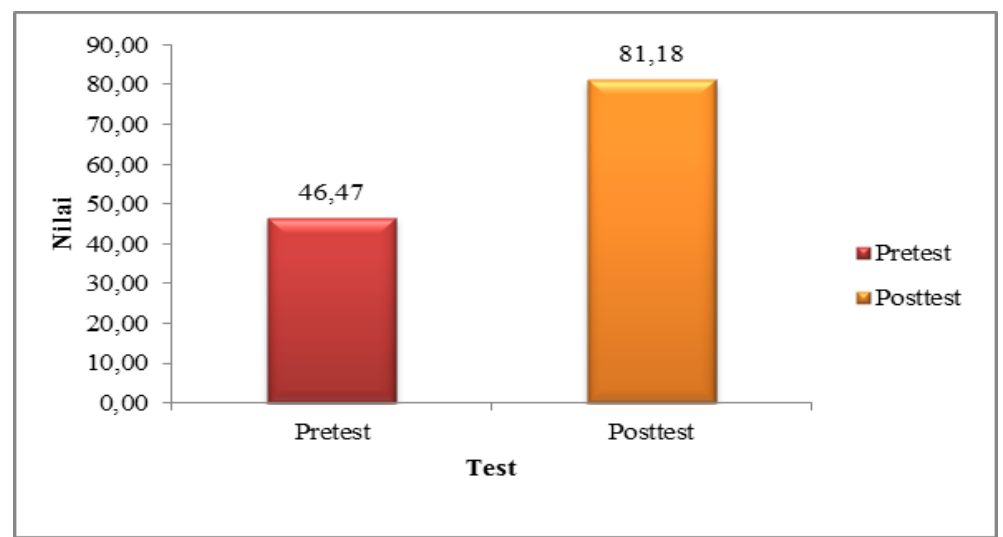

Gambar 4. Diagram hasil Analisis Pretest dan Posttest Peserta Didik

Data yang telah diperoleh berdasarkan soal tes yan dikerjakan peserta didik merupakan data yang memperlihatkan kemampuan pemahaman konsep peserta didik. Penilaain dilakukan sesuai dengan pedoman penskorang yang telah dibuat sebelumnya. Adapun presentase hasil tes dapat dilihat pada table 10 berikut.

Tabel 10. Hasil Presentase kemampuan pemahaman konsep peserta didik di kelas X MIPA 1

\begin{tabular}{cccc}
\hline Nilai & \multicolumn{2}{c}{ Kemampuan Pemahaman } & Konsep Peserta Didik \\
& Frekuensi & $\%$ & Kategori \\
\hline $85-100$ & 5 & 29,4 & Sangat Baik \\
$75-84$ & 7 & 41,2 & Baik \\
$56-74$ & 5 & 29,4 & Cukup \\
$41-55$ & 0 & 0 & Kurang \\
$0-40$ & 0 & 0 & Sangat Kurang \\
\hline Jumlah & 17 & 100 & - \\
\hline
\end{tabular}

Dapat dilihat bahwa hasil presentase kemampuan pemahaman konsep keseluruhan siswa dengan kategori sangat baik sebesar 29,4\%. Pada kategori baik yaitu sebesar 41,2\%. Dan pada kategori cukup sebesar $29,4 \%$. Siswa yang dikategorikan sangat baik apabila semua indikator pemahaman konsep terpenuhi dan jawaban benar. Siswa dikategorikan baik apabila indikator pemahaman konsep salah satunya tidak terpenuhi. Siswa dikategorikan cukup apabila hanya beberapa indikator yang terpenuhi. 
Siswa dikategorikan kurang apabila hanya beberapa indikator terpenuhi tetapi jawaban salah. Siswa yang dikategorikan sangat kurang apabila semua indikator tidak terpenuhi.

Tabel 11. Nilai Pretest dan posttest Per Indikator

\begin{tabular}{|c|c|c|c|c|c|c|c|c|c|c|c|}
\hline \multirow{2}{*}{ No. } & \multicolumn{10}{|c|}{ Indikator Ke- } & \multirow{3}{*}{$\begin{array}{l}\text { Rata- } \\
\text { rata }\end{array}$} \\
\hline & \multicolumn{2}{|c|}{1} & \multirow{2}{*}{$\begin{array}{l}2 \\
3\end{array}$} & \multirow{2}{*}{$\begin{array}{l}3 \\
4\end{array}$} & \multirow{2}{*}{$\begin{array}{l}4 \\
5\end{array}$} & \multicolumn{2}{|c|}{5} & \multicolumn{3}{|c|}{6} & \\
\hline $\begin{array}{l}\text { Butir } \\
\text { Soal }\end{array}$ & 1 & 2 & & & & 6 & 7 & 8 & 9 & 10 & \\
\hline Pretest & 7,6 & 7,0 & 3,5 & 8,2 & 2,3 & 4,1 & 2,3 & 5,3 & 4,7 & 1,2 & 4.62 \\
\hline Posttest & 9,4 & 8,2 & 6,5 & 8,2 & 8,8 & 8,2 & 7,6 & 8,8 & 6,5 & 8,8 & 8,11 \\
\hline
\end{tabular}

Diagram Jumlah Nilai Pretest dan Posttest Per Indikator pemahaman konsep pada kelas X MIPA 1 disajikan dalam Gambar 4.

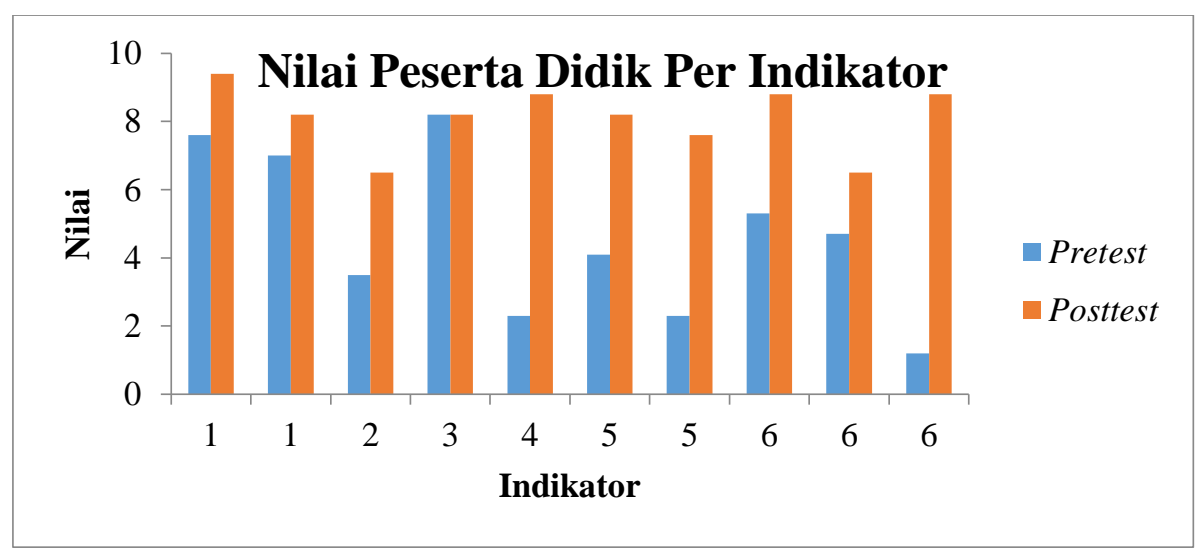

Gambar 4. Diagram Jumlah Pretest dan Posttest Per Indikator

Dari Gambar 4. di atas terlihat bahwa setelah menggunakan media, indikator pemahaman konsep peserta didik terpenuhi dan adanya peningkatan. Jika pada pretest jumlah nilai peserta didik pada soal 1, 2 , 3,5 ada 7,$6 ; 7,0 ; 3,5 ;$ dan 2,3. Dan pada indikator 4, 6,7,8,9, 10 ada 8,2; 4,1;2,3;5,3; 4,7; dan 1,2. Dengan rata-rata nilai pretest peserta didik yaitu 4,62. Pada posttest setelah menggunakan media jumlah peserta didik yang memenuhi indikator $1,2,3,5$ ada 9,$4 ; 8,2 ; 6,5$; dan 8,8 . Dan pada indikator $4,6,7,8,9,10$ ada 8,$2 ; 8,2 ; 7,6 ; 8,8 ; 6,5 ;$ dan 8,8 .

Dengan rata-rata nilai posttest 8,1 . Dapat dilihat pada perbandingan sebelum dan sesudah menggunakan media pembelajaran Toys for Physics pada pemahaman konsep setiap indikator mengalami peningkatan. Berdasarkan tabel diatas diperoleh peningkatan pemahaman konsep peserta didik dilihat dari nilai pretest dan posttest pada tahap penerapan diperoleh $N$-gain 0,65 dan termasuk dalam kategori peningkatan sedang.

Berdasarkan data di atas, maka media pengembangan Toys for Physics dapat digunakan sebagai alternatif media pembelajaran untuk meningkatkan pemahaman konsep peserta didik.

\section{KESIMPULAN}

Penelitian pengembangan ini menghasilkan produk berupa media pembelajaran Toys for Physics. Media pembelajaran Toys for Physics ini dikembangkan dengan model pengembangan (R\&D) model 4D (Define, Design, Develop, Disseminate). Berdasarkan hasil validasi oleh ketiga validator diperoleh 
kelayakan media pembelajaran sebesar 3.25 dengan kategori baik dan rerata reabilitas semua validator sebesar 92\% dengan kategori sangat reliabel, sehingga media pembelajaran Toys for Physics layak digunakan dalam pembelajaran.

Respon peserta didik terhadap media pembelajaran Toys for Physics yang dikembangkan sebesar 3.42 sehingga diperoleh persentase rerata $91 \%$ dan dapat disimpulkan bahwa respon peserta didik terhadap pembelajaran dengan media pembelajaran Toys for Physics adalah baik. Peningkatan pemahaman konsep peserta didik dilihat dari nilai pretest dan posttest pada tahap penerapan diperoleh $\mathrm{N}$-gain 0,65 dan termasuk dalam kategori peningkatan sedang.

\section{REFERENSI}

[1] Arsyad, Azhar. 2017. Media Pembelajaran. Jakarta: PT Raja Grafindo Persada.

[2] Sudjana, Nana dan Ahmad Rivai. 2017. Media Pengajaran. Bandung: Sinar Baru Algensindo.

[3] Pranata, E. (2016). Implementasi Model Pembelajaran Group Investigation (GI) Berbantuan Alat Peraga Untuk Meningkatkan Kemampuan Pemahaman Konsep Matematika. JPMI (Jurnal Pendidikan Matematika Indonesia), 1(1), 34-38.

[4]Ningsih, S. Y. (2017). Peningkatan Kemampuan Pemahaman Konsep Siswa Melalui Pendekatan Matematika Realistik Di Smp Swasta Tarbiyah Islamiyah. MES (Journal of Mathematics Education and Science), 3(1)

[5] Trianggono, M. M. (2017). Analisis Kausalitas Pemahaman Konsep Dengan Kemampuan Berpikir Kreatif Siswa Pada Pemecahan Masalah Fisika. Jurnal Pendidikan Fisika Dan Keilmuan (JPFK).

[6] Purwanto, N. 2017. Psikologi Pendidikan. Bandung: PT Remaja Rosdakarya.Sudjana, Nana dan Ahmad Rivai. 2017. Media Pengajaran. Bandung: Sinar Baru Algensindo.

[7] Ihsaan, A. 2017. Pengembangan Media Pembelajaran Fisika Berbasis Model Educational Games Guna Meningkatkan Minat dan Hasil Belajar Melalui Rolling Box (Ro-Box) Bagi Peserta Didik Kelas X SMA N 1 Prambanan Klaten.

[8] Sakti, W.R., Subronto, S., \& Sumarna, S. (2017). Pengembangan Media Pembelajaran Games Roulette Fisika Untuk Meningkatkan Motivasi Dan Hasil Belajarpeserta Didik Sma N 1 Prambanan Klaten.

[9] Susanti, I. (2014). Pengembangan Permainan Tradisional Jamuran Sebagai Media Pembelajaran Tata Nama Senyawa Di Kelas X Sma (The Development Tradisional Games Of Jamuran As Learning Media On Compound's Nomenclature For X Class In Senior High School). Unesa Journal of Chemical Education, 3.

[10] Sugiyono, Metode Penelitian Kuantitatif Kualitatif Dan R\&D, Bandung: Alfabeta, Cet. Ke-13, 2011

[11] Purwanto, N. 2017. Psikologi Pendidikan. Bandung: PT Remaja Rosdakarya.Sudjana, Nana dan Ahmad Rivai. 2017. Media Pengajaran. Bandung: Sinar Baru Algensindo

[12] Widoyoko, Eko Putro S. 2018. Teknik Penyusunan Instrumen Penelitian. Yogyakarta: Pustaka Pelajar.

[13] Triyanto, (2009). Mendesain Model Pembelajaran Inovatif Progresif. Surabaya: Kencana. 
[14] Agustina, L. (2016). Upaya meningkatkan kemampuan pemahaman konsep dan pemecahan masalah matematika siswa SMP Negeri 4 Sipirok kelas VII melalui pendekatan matematika realistic (PMR). EKSAKTA: Jurnal Penelitian Dan Pembelajaran MIPA, 2016, 1.1.

[15] Istiqomah, R. M. 2019. Pengembangan bahan ajar fisika SMA berbasis masalah menggunakan android untuk meningkatkan kemampuan evaluasi peserta didik. Jurnal Riset dan Kajian Pendidikan Fisika. Vol 6 No 1. 